\title{
Disease Response Sequence Number
}

National Cancer Institute

\section{Source}

National Cancer Institute. Disease Response Sequence Number. NCI Thesaurus. Code C117400.

An identifier that describes the relative position of disease response data within a series. 